\title{
Studies on the Removal of Heavy Metals from Aqueous Solution Using Immobilized Typha angustata $L$.
}

\author{
Muhammad Aqeel Ashraf ${ }^{*}$, Nur Hayati Hussin', Mohammadreza Gharibreza ${ }^{2}$ \\ ${ }^{1}$ Department of Geology, University of Malaya, Kuala Lumpur 50603, Malaysia
}

${ }^{2}$ Soil Conservation and Watershed Management Research Institute, P.O. Box 13445-1136, Tehran, Iran, Corresponding Author: aqeelashraf@um.edu.my Tel: 0060379677199 Fax: 0060379675149

This is an open access article distributed under the Creative Commons Attribution License, which permits unrestricted use, distribution, and reproduction in any medium, provided the original work is properly cited

\section{ARTICLE DETAILS}

Article history:

Received 26 October 2016 Accepted 10 December 2016 Available online 9 January 2017

Keywords:

Immobilized Typha angustata L., heavy metal ions, aqueous solution, sorption capacity.

\section{ABSTRACT}

The sorption capacity of Immobilized Typha angustata L. for the removal of metal ions $\left(\mathrm{Fe}^{3+}, \mathrm{Pb}^{2+}, \mathrm{Zn}^{2+}, \mathrm{Cr}^{3+}\right.$ and $\left.\mathrm{Cd}^{2+}\right)$ were studied using batch experiments. The residual metal ion concentrations were investigated using AAS. The influence of factors such as contact time, initial concentration, ionic strength $\mathrm{pH}$ and temperature were investigated. The metal ion sorption capacity by IBCC decreases with increasing ionic strength but increases with increasing $\mathrm{pH}$ values and initial metal ion concentration. The sorption rate for the metal ions was rapid for the first 30 minutes and equilibrium was established within 2 hrs. The maximum sorption capacity for $\mathrm{Fe}^{3+}, \mathrm{Pb}^{2+}, \mathrm{Cd}^{3+}, \mathrm{Cr}^{2+}$, and $\mathrm{Zn}^{2+}$ were found to be $98.65,96.36,90.57,84.38$ and 80.28 respectively. From the experimental work on the sorption capacity of IBCC sorbent, our result showed that the abundantly wasted Typha angustata L. could be turned into an environmentally friendly, and cost effective sorbent for the removal of heavy metalions from waste water

\section{Introduction}

Due to the great amount of industrial activities, contamination of the environment by heavy metals has became a serious problem. Many of these toxic metals enter the environment through fossil fuel combustion as well as mining and smelting process (Wu et al., 2008). The natural process of metal transportation between the soil and water concentrates heavy metal contamination in the environment (Wuyep et al., 2007). Once in the environment, metals are difficult to remediate and can adversely impact human health. Even in low doses, metals which do not have distinguishable odour and colour characteristics, still pose a major threat. Current technologies for cleaning up heavymetals contaminated soils involve excavation and reburial in landfills. This process is expensive and usually reserved for small areas, and the metals are still not isolated from the environment. Contaminated waters are typically detoxified through the use of ion exchange and activated charcoal filters which are not only costly, but nonselective for heavy metals removal (Ogali et al.,2008). Due to the high cost of these methods, there is need for the development of a more costeffective method.

Bioremediation has emerged as an inexpensive solution. Many researchers have studied the use of live microbial systems for the purpose of remediating contaminated waters (Volesky, B. 2007). A few plant species have shown a remarkable resistance to heavy metals such as copper, zinc, and lead (Wuyep et al., 2007). This ability to grow in highly contaminated areas is thought to be due to the evolution of chemical functional groups which inhibit the toxicological effects of the heavy metals (Toti et al., 2008). Phyto-chelations and proteins within the plant may be produced in large concentration to bind the metals and reduce their harmful effects (Chamarthy et al., 2009). Therefore, plants that grow in contaminated areas should show a greater ability to recover heavy metals and may be a good source for naturally occurring biological compounds that have potential for contaminant remediation.

Although live biological systems work well for low concentrations, they cannot survive the high levels that are found in seriously contaminated areas and industrial influents. The use of non-living biomaterial containing metals-binding compounds would have the advantage of non requiring care and maintenance as well as being useful in remediating areas with high levels of contaminants that would otherwise kill live systems. Hence a plant such as Typha angustata $L$. which has the ability to tolerate heavy metals and adverse environments might contain natural metal binding compounds and could be a possible source for bioremediation of heavy metals in waste water (Alabuk et al., 2007)
The immobilization of Typha angustata L. biomasses involves the trapping of the biomass within the matrix of the polymer with sodium alginate and calcium chloride solutions to give a good biosorbent materials. However, biosorbents are hard enough to withstand the application of pressures, have water retention capacity, high and fast sorption uptake. Also because of immobilization, the biosorbents so obtained offer easy and convenient usage compared to free biomass, which is easily biodegradable (Volesky et al., 2007). One of the most valued properties of these modified product is their water absorbency and dehydration behaviour (Lee et al., 2009). They also exhibit suitable hydrophilicity and high swelling capacity. The target in this study is to immobilized the Typha angustata L. with sodium alginate with the objective of using the products as a sorbent for the removal of heavy metals in waste water.

\section{Material and Methods \\ MATERIALS}

Sodium alginate, Calcium chloride, Sodium hydroxide, Hydrochloric acid, Lead nitrate, Ferric chloride, Cadmium (II) nitrate, Chromium (III) nitrate, Zinc nitrate and were obtained from the British Drug House(BDH).The chemicals were of analytical grade and were used as supplied. Typha angustata L. was obtained from Perak, Malaysia METHODS

Preparation of Typha angustata L. Calyx Sample The Typha angustata L. sample was sundried, decoated and milled into powder, then sieved through a $100 \mu \mathrm{m}$ sieve screen to obtain fine powder and packaged separately in polyethylene bag for further use (wuyep et al., 2007).

Preparation of Sodium Alginate and Calcium Chloride Solutions

Sodium alginate was made by weighing $4.00 \mathrm{~g}$ and making it up to $100 \mathrm{~cm}^{3}$ mark with distilled water in a volumetric flask and left over night for complete dissolution to give $4 \% \mathrm{w} / \mathrm{w}$ solution. Calcium chloride( $0.12 \mathrm{M}$ ) was prepared by weighing $26.28 \mathrm{~g}$ into 1 litre volumetric flask and making it up to the mark with distilled water (wuyep et al., 2007). Synthesis of Typha angustata L. Immobilized

$25 \mathrm{~cm}^{3}$ viscous layers of dissolved Typha angustata L. sample was mixed with $25 \mathrm{~cm}^{3}$ of $4 \%$ stock solution of Sodium Alginate and stirred vigorously for even mixing in $250 \mathrm{~cm}^{3}$ beaker. The mixture was then transferred into another beaker containing $30 \mathrm{~cm}^{3}$ of $0.12 \mathrm{M}$ Calcium chloride solution. The reaction was allowed retention time of $1 \mathrm{hr}$ for complete precipitation. The precipitated blend solid of the sample was filtered and dried at room 
temperature for $24 \mathrm{hrs}$. The dried solid was stored in polyethylene bag for further use (wuyep et al., 2007).

The above procedure was followed by mixing another set of blend compounds with $4 \%$ of the stock solution of Sodium alginate and Typha angustata $L$. in the ratio of 100:0, 95:5, 90:10, 85:15 and 80;20 which were designated as B1, B2, B3, B4and B5 respectively. The dried solids were separately stored in polyethylene bags for further use (wuyep et al., 2007). Preparation of Synthetic waste water

The metal ions chosen for this study were $\mathrm{Pb}, \mathrm{Fe}, \mathrm{Cr}, \mathrm{Cd}$ and $\mathrm{Zn}$. The standards of these metal ion solutions were prepared from their salts by dissolving 1.60, 2.90, 7.70, 2.29 and $3.78 \mathrm{~g}$ of Lead nitrate, Ferric chloride, Chromium (III) nitrate, Cadmium (II) nitrate and Zinc nitrate in distilled water respectively and made up to 1 litre in a Volumetric flask that gave the stock solution of $1000 \mathrm{ppm}$ of the metal ions. Serial dilution of $200 \mathrm{ppm}$ of each metal ion solution was prepared with distilled water. The synthetic waste water was kept for further use.

Sorption experiment using Immobilized Typha angustata $L$.

The experiments were carried out in the batch mode for the measurement of adsorption capacities. From $200 \mathrm{ppm}$ of each metal ion solution, $50 \mathrm{~cm}^{3}$ was taken into a $250 \mathrm{~cm}^{3}$ conical flask and $0.2 \mathrm{~g}$ of the IBCC was added corked with a rubber bung and shaken with a flask shaker for 2 hours at room temperature $\left(30^{\circ} \mathrm{C}\right)$ at $150 \mathrm{rpm}$. The separation of the adsorbents and solutions were carried out by filtration with whatman filter paper No 42 and the filtrates were stored in Sample cans for use. The residual metal ion Concentrations were determined using Atomic Absorption Spectrophotometer AAS Pyeunicam Model SP9 (Chamarthy et al., 2009; Osemeahon, 2003).

The percentage adsorption was calculated using the following equation \%Adsorption $=\left[\left(\mathrm{C}_{\mathrm{i}}-\mathrm{C}_{\mathrm{f}} / \mathrm{C}_{\mathrm{i}}\right)\right] \mathrm{x} 100$

Where $\mathrm{C}_{\mathrm{i}}=$ Initial metal ion Concentration and $\mathrm{C}_{\mathrm{f}}=$ Equilibrium metal ion Concentration (Barminas et al., 2005).

Determination of the effect of $\mathrm{pH}$ on Sorption Capacity.

The Sorption Capacity of the $0.2 \mathrm{~g}$ of Immobilized Typha angustata L. with $50 \mathrm{ml}$ of $200 \mathrm{ppm}$ of various metal ion solutions at different $\mathrm{pH}$ values(1.0 to 6.0 ) were shaken for 2 hours using a flask shaker at $30^{\circ} \mathrm{C} .1 .0 \mathrm{M} \mathrm{HCl}$ and $1.0 \mathrm{M} \mathrm{NaOH}$ were used to adjust the $\mathrm{pH}$ of the solutions as the case may be. The residual metal ions were measured using Atomic Absorption Spectrophotometer AAS Pyeunicam Model SP9

(Chamarthy et al., 2009).

Determination of the effect of Contact time on Sorption Capacity.

The Sorption Capacity of IBCC for the various metal ions were determined. Set of samples consisting of $0.2 \mathrm{~g}$ of the dried IBCC and $50 \mathrm{ml}$ of the metal ion solutions were introduced into $250 \mathrm{ml}$ conical flasks, corked with rubber bungs and climbed on a flask shaker. As the samples were undergoing agitation on the shaker, they were removed one after the other at a predetermined time interval ranging from 0.5 to 24 hours at $30^{\circ} \mathrm{C}$. The solutions were filtered and analyzed for the residual metal ions using AAS (Chamarthy et al., 2009). Determination of the effect of Initial metal ion Concentrations on Sorption Capacity.

The Sorption Capacity of various samples consisting of $50 \mathrm{ml}$ each of different metal ion concentrations ranging from $5 \mathrm{ppm}$ to $100 \mathrm{ppm}$, each containing $0.2 \mathrm{~g}$ of the dried IBCC were prepared and shaken for 2 hours on a flask shaker at $30^{\circ} \mathrm{C}$.The solutions were filtered and analyzed for residual metal ions using AAS (Chamarthy et al., 2009).

Determination of the effect of temperature on Osemeahon et al., (2007); Wuyep et al., (2007) and Wu et al., (2008).

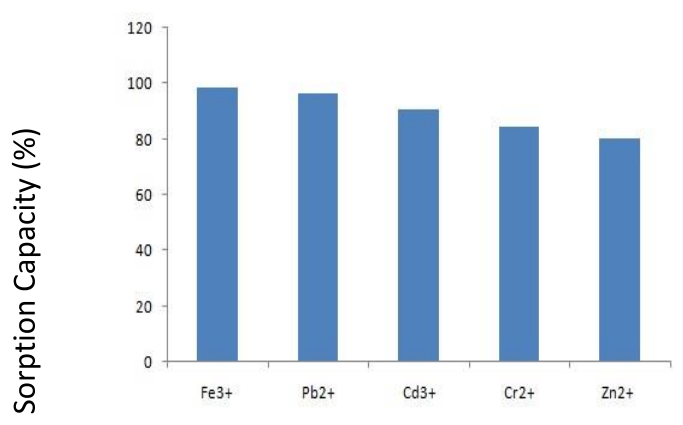

Figure 1: Sorption capacity of metal ions by Typha angustata L.

The effect of $\mathrm{pH}$ on the maximum sorption capacity of the metal ions studied were 4 for $\mathrm{Cd} 2+, 6$ for $\mathrm{Pb} 2+$, and 5 for Fe3+, $\mathrm{Cr} 3+$, and $\mathrm{Zn} 2+$. The
$\mathrm{pH}$ of the sorption media is related to the metal sorption - mechanism of the surfaces from the water and reflected the nature of the physicochemical interaction of the ions in solution and nature of the sorption sites (Osemeahon et al., 2007). Therefore, it can be suggested that the differences in the $\mathrm{pH}$ optima for different metal mioents aclo uld probably be due to the different solution chemistry of the metal ion (Lee et al., 2009).

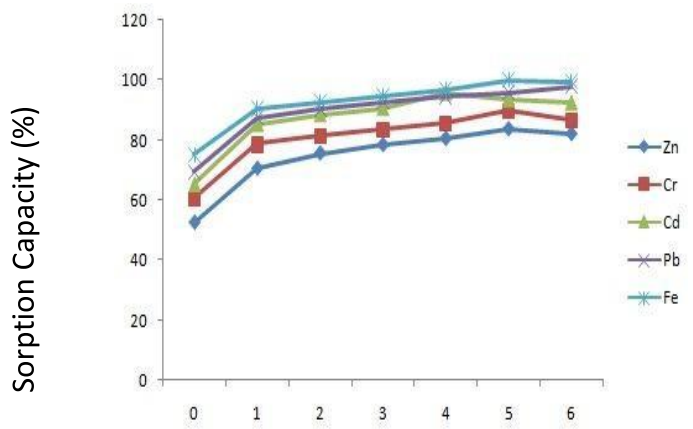

Figure 2: Effect of $\mathrm{pH}$ on sorption capacity of Typha angustata $\mathrm{L}$. The $\mathrm{pH}$ influences the equilibrium metal ion uptake in aqueous solution. This happens because of counter reaction of the competiting hydrogen ion as well as the chemistry of the active binding sites of the sorbent (Yenpeng et al., 2007).

Increasing the $\mathrm{pH}$ leads to precipitation of insoluble hydroxide or hydrated oxide, thereby lowering the metal ion availability for sorption. On the other hand, a decrease in $\mathrm{pH}$ results in the increase in the hydrogen ion concentration and hence possible competition for binding sites (Yenpeng et al., 2007).

Effect of Ionic Strength on Sorption of metal ions.

Industrial wastes and natural water often contain dissolved salts which compete with heavy metal ions for binding sites on the sorbent carbon chain (Osemeahon et al., 2008). There is the need to ascertain the influence of this factor on IBCC.

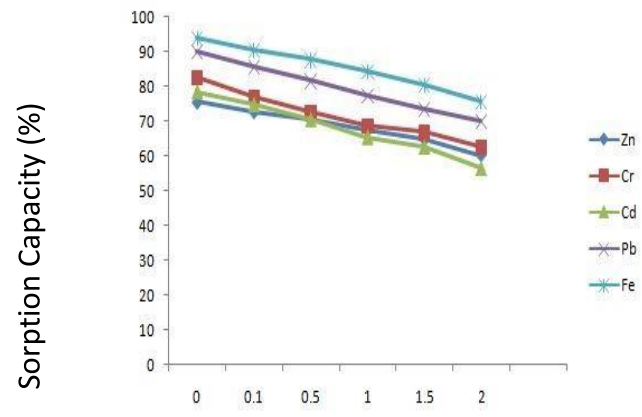

Fig. 3: Effect of ionic strength on sorption capacity of Typha angustata $L$

The effect of the ionic strength on removal of the heavy metal ions from the aqueous solution by Typha angustata $L$. is represented in Figure 3. It can be observed that the sorbent showed a decrease in sorption capacity with increase in ionic strength for all the metal ions studied. The decrease in sorption capacity with increasing ionic strength is primarily attributed to the reduction in difference in the ionic osmotic pressure between the sorbent and the external solution (Lee et al., 2009; Osemeahon et al., 2008). The difference in osmotic pressure between the sorbent and the external solution decreases as the ionic strength of external solution increases. Therefore, the sorption of metal ion decreases when the ionic strength of external solution increases (Lee et al., 2009).

From this experiment, the coexistence of metal ions in same solution caused the interference with the performance of IBCC sorbent. Therefore the pretreatment of the effluent to remove the interfering ion appears to improve the efficiency of the sorbent (Kuyucak et al., 2008).

Effect of Contact Time on metal ions Sorption. The effect of contact time on sorption capacity of metal ions by Typha angustata L. is shown in Figure 4. Equilibrium was established after 2 hours of contact time for all the metal ions, but high sorption rates were observed during the first 30 minutes. Equilibrium time of 30 minutes was recorded for $\mathrm{Pb}^{2+}$ and two hours for the rest of the metal ions. The rapid sorption of metal ions may be attributed to highly porous structure of the sorbent which provide readily access for large surface area for the sorption of the metal ions to the binding 
sites (Alabuk, et al., 2007).

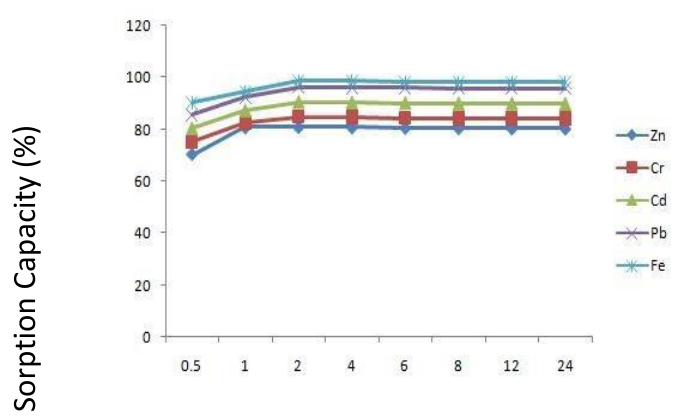

Figure 4: The effect of the contact time on sorption capacity of IBCC. This result demonstrates that the sorbent can compete favourably with other industrial sorbents in terms of kinetics, hence, equilibrium time is one of the important parameters for an economical wastewater treatment system. Effect of Initial metal ion Concentration on Sorption.

The result of metal ions sorption by the Typha angustata $L$. as a function of initial metal ion concentration is shown in Figure 5. It can be observed that the removal efficiency of the metal ions by the sorbent increases with the increase in initial concentration but leveled up however at certain point of the initial concentration.

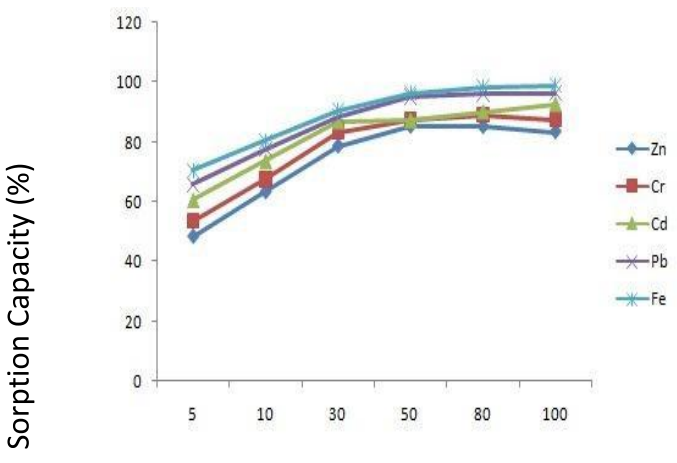

Figure 5: Effect of initial concentration on sorption capacity of IBCC.

This behaviour can be explained in term of increase in flux of the metal ions. The flux of the metal ions varies directly with the metal ion concentration and hence there should be an increase in flux with increase in initial concentration (Xiao et al., 2009; Osemeahon, 2007). The constant requirement observed for all metal ions explained the point of saturation. One of the problems of using conventional methods for the removal of the metal ions from aqueous systems is sometimes effectiveness, especially when the metal ion is present at a very low concentration (Toti et al., 2008). The behaviour of IBCC even at low concentration $5 \mathrm{ppm}$ shows that IBCC sorbent may be used in an attempt to improve the efficiency of metal ion removal from aqueous solution at low metal ion concentrations.

Effect of Temperature on heavy metal ions sorption. Figure 6 indicate the effect of temperature on the sorption of metal ions by Typha angustata $L$.. It can be seen that the sorption capacity decreases with an increase in temperature. The result of this work is in agreement with previous reports (Volesky, B. 2007; Lee et al., 2009; Ju et al., 2008; Osemeahon et al., 2003; Mahavi et al., 2008 and Ogali et al., 2008). From the graph, it can be seen that the sorption capacity of the metal ions decreases sharply from $30^{\circ} \mathrm{C}$ to $50^{\circ} \mathrm{C}$. The decrease of the polymer matrix performance with increase in temperature may be due to the following factors:

i. The inherent molecular structure of the polymer matrix formed (Ogali et al., 2008).

ii. Concentration of the immobilized sample molecules with increase in temperature to give a more compacted form of the polymer matrix which causes the pore to be narrower and suction sites be hidden or inaccessible to the water molecules (Barminas and Osemeahon, 2005). iii. The sorption mechanism may be a physical adsorption Physical adsorption are normally exothermic, thus the extent of adsorption generally increases with decreasing temperature (Ju et al., 2008)

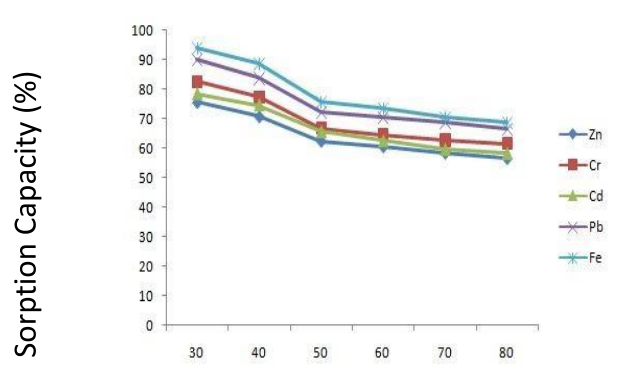

Figure 6: Effect of temperature on sorption capacity of Typha angustata L. Conclusion

The sorption of $\mathrm{Zn}, \mathrm{Cr}, \mathrm{Cd}, \mathrm{Pb}$ and $\mathrm{Fe}$ ions by Typha angustata $\mathrm{L}$. has been shown to be dependent upon $\mathrm{pH}$, with best sorption occurring between $\mathrm{pH}$ 5 and6. This effect in $\mathrm{pH}$ suggests that the sorption mechanism may be an ion-exchange type process. Also, the sorption mechanism for these metals is a stable, rapid process which implies that the sorption is taking place on the cell wall surface of the Typha angustata L.. The experiments have demonstrated that Typha angustata $\mathrm{L}$. possessed the ability to bind appreciable amounts of $\mathrm{Zn}, \mathrm{Cr}, \mathrm{Cd}, \mathrm{Pb}$ and Fe ions as compared with other biosorbents. This ability to remove heavy metals from solution indicates the tremendous potential that the Typha angustata L. could have for cleaning the environment and industrial waste effluents from toxic metal ions.

\section{Acknowledgements}

We would like to express our thanks to the Department of Irrigation and Drainage and the Department of Environment, Malaysia for their cooperation in performing this study. We would also like to express our gratitude to the University of Malaya through research grant BK006-2013, RG257-13AFR, FP038-2013B for supporting this study. We are most grateful and would like to thank the reviewers for their valuable suggestions, which led to a substantial improvement of the article.

\section{References}

[1] Alabuk A, T Akar, S. Tumali and Gedikli S. (2007). Biosorption of $\mathrm{Ph}$ (ii) by industrial main of Saccharomyces cerevisiae immobilized on the biomatrix of conebiomass of pinus nigra: Equilibrium and mechanism analysis. J. Chem. Eng., 131: 293- 300

[2] Assamudo N.U., Dada A.S. and Ezeronye O.U. (2005) Treatment of waste water by waste cassava peels Afr. J. Biotechnol. 4 (13): 1548- 1553

[3] [Barminas, J. T. (2004) Rheological Properties of KonKoli (Maesopsis Eminii) Seed. Ph. D. Dissertation, Federal University of Technology, Yola.

[4] Barminas, J. T., and Eremosele, I.C. (2002). Rheological Properties and Potentials Industrial Application of Konkoli (Maesopsis eminii) Seed Gum. In: Ph. D. Thesis, Federal University of Technology, Yola.Barminas J.

[5] Osemeahon, S. A; (2005) Development of sodium alginate and konkoli gum-grafted-polyacryamide blend membrance. Sc. Forum J. pure and Appl. Sci. 1: 70-79

[6] Chamarthy, S., Chung, W., Marshall W. E., (2009). Adsorption of Selected Toxic Metals by Modified pea nut shells. J. Chem. Technol Biotechnol. 75:791-797

[7] Ercole, C. Veglio F. Toro, L. Ficara G. and Lepidi, A. (2006) Immobilisation of microbial cells for metal adsorption and desorption. In: Mineral Bio-processing ii. Snowboard. Utah pp202-209

[8] Ju, K. H., Kim, S. J., Seon J. K and Lee J. M., (2008). $\mathrm{pH} /$ temperature- responsive semi-IPN hydrogels copose of alginate and poly(N-isopropylacrylamide). J. Appl. Polymer sci., (83): 1128- 1139 
[9] Kuyucak N. and Volesky, B. (2008) Biosorbents for recovery of metals from industrial solutions. Biotechnol Left., 10 (2): 137- 142

[10] ee W. and Lin G., (2009). Super-sorbent polymeric material viii: swelling behavior of polymeric cross-linked poly (sodium acrylate-cotrimethylmetaacrylolioxyethyl ammonium iodide) in aqueous solution. J. Appl. Polymer Sc. 79: 1165- 1674

[11] Mahavi, P. (2008) Use of tea waste as a bio-absorbent for removal of heavy metal from waste water. Chemosphere 54: 22-29

[12] Ogali R. E.; Akaranta, O. and Aririguzo, V. O.; (2008) Removal of some metal ion from aqueous solution using orange mesocarp, Afti. J. Biotechnol. Vol. 7 (17) pp3073- 3076

[13] Osemeahon, S. A. (2003) Sorption of metal Ions in Aqueous Solution by Grafted Membrane. M. Tech. Thesis. Federal University of Technology, Yola.

[14] Osemeahon, S. A, Bannmas J. T., Aliyu B. A, Maina H. M. (2007) Preliminary evaluation on the application of grafted membrance for sorption of copper and lead ions in aqueous solution. Inter. J. physical Sc. 2(11): 294-299.

[15] Osemeahon, S. A, Barminas J. T. Aliyu B. A and Nkafamiya, I.I. (2008). Application of grafted membranes for sorption of $\mathrm{Cd} 2+, \mathrm{Fe} 2+$ and $\mathrm{Zn} 2+$ in aqueous solution. J. Pure \& Appl. 2(3):32-36

[16] Toti, S. U., Mahadevappa Y., Kumaresh K., Soppimath S. and Aminabhavi T. M. (2008). Pervaporation separation of water and acetic acid mixture through blend membrance of sodium alginate and guar gum grafted polycrylamide. J. Appl. Polymer Sc. 83:259-277

[17] Xiao, C.; Lihui W. and Lina Z., (2009). Improvement of physical properties of cross linked alginate and carboxymethyl Konjac glucomannan blend films J. Appl. Polymer. (84):2554-2560

[18] Volesky, B. (2007), Removal and Recovery of Heavy Metal by Biosorption: In biosorption of heavy metal. Boston CRC Press pp743

[19] Wu S and Chen JP, (2008). EDTA study on EDTA chelated copper adsorption by granulated activated carbon, Society for Chemical Industry, J. Chem. Technol. Biotechnol. 75:791-797

[20] Wuyep, P. A; Chuma, A. G., Awodi, S. and Nok A. J. (2007). Biosorption of $\mathrm{Cr}, \mathrm{Mn}, \mathrm{Fe}, \mathrm{Ni}$ and $\mathrm{Cu}$ metals from refinery effluent by calcium alginate immobilized mycelia of polyporus squamosunolos; Sc. Res. Essay, 2(7): 217-221.

[21] Yenpeng, T. and Sung, G. (2005). Use of polyvinyl alcohol as a cell immobilization matrix for copper biosorption by yeast cells. J. Chem. Technol. Biotechnol. 75:541-546 